\title{
ENTREPRENEURIAL SELF-EFFICACY DIMENSIONS AND HIGHER EDUCATION INSTITUTION PERFORMANCE
}

\author{
MUHAMMAD SHUKRI BAKAR \\ AZAHARI BIN RAMLI \\ School of Business Management \\ Universiti Utara Malaysia \\ NAJAFI AUWALU IBRAHIM \\ IBRAHIM GARBA MUHAMMAD \\ Department of Business Administration and Entrepreneurship \\ Bayero University, Kano, Nigeria
}

\begin{abstract}
A detailed literature review provided consistent justification for the effect of entrepreneurial self-efficacy (ESE) on entrepreneurial intention. Recently, the literature yielded similar relationship on the link between ESE to firm performance. Although there are a significant number of studies on this effect that was mostly conducted in the private sector, they mainly focused on the composite ESE construct. The present study replicated and validated these findings with data from the public sector, specifically, higher education institutions (HEIs). Moreover, the study focused on the individual effect of all dimensions of ESE identified by Chen, Greene, and Crick (1998). Using PLS-SEM and non-probability sampling, the data were collected from 180 academic leaders from selected HEIs in Kano, Nigeria. The findings indicated that three dimensions of ESE (financial control ESE, innovation ESE, and risk taking ESE) were found to be significantly related to HEI performance, while two (management ESE and marketing ESE) were insignificantly related to HEI performance. The practical implication and suggestion for future study are also discussed.
\end{abstract}

Keywords: Entrepreneurial self-efficacy, HEIs, Performance

Received: 03/04/2017 Revise: 18/06/2017 Accepted: 05/07/2017 Publish: 27/7/2017

\section{Introduction}

The growth and success of an organisation largely depend on its employees' ability to innovate and utilise the few available resources 
at their disposal (Danish \& Usman, 2010). This has become crucial in today's environment that have been characterised by rapid and continuous change, hence, creating a lot of difficulties for management in both private and public sectors. The pressures facing public sector organisations are increasing on a daily basis, thus demand for efficiency and effectiveness; as well as quality, timely output, and information are the order of the day (Kearney \& Morris, 2015). Higher education institutions (HEIs) are no exception, having been recognised as a critical stakeholder in providing basic scientific knowledge needed for industrial innovation, through research, teaching, and learning (Ferretti \& Parmentola, 2015). However, HEI performance in Nigeria has deteriorated due to neglect.

This poor performance has been attributed to many factors, such as obsolete facilities and inadequate funding (Ahmad, Halim, Ramayah, \& Rahman, 2013; Bakar, 2014), but the primary identified factor is poor quality leadership that lacks the ability to effectively and efficiently utilise the few available resources at their disposal (Dike, 2014). Moreover, it has been documented that one of the processes of HEIs to increase performance is by becoming "entrepreneurial" in nature (Bakar \& Mahmood, 2014). This requires a drastic change in their structure as well as management styles and practices, to become more capable of responding to the dynamic nature of today's environment (Callagher, Blixens, Horst, \& Husted, 2015). In addition, HEIs are expected to play an active role toward the economic development of their respective country (Ahmad et al., 2013). Consequently, HEIs are encouraged to engage the services of highly qualified individuals that have the ability to correlate their knowledge and skills to students and organisational performance; and by extension to economic development (Amin, Ismail, Rasid, \& Selemani, 2014). For example, Lew (2009) argued that HEI employees are vital in enhancing research quality, and implementing academic programmes that significantly impacts students and prepares them for the challenges of the wide world. In addition, leaders' characteristics are paramount when talking about organisational performance. However, despite its importance to organisational performance, less attention has been given especially in HEIs (Elliott, 2008; Wahab, Mahmood, \& Bakar, 2015).

The present study aimed to introduce the concept, which has largely been employed within the private sector, of using Social Cognitive Theory (SCT) to establish its influence on HEI performance. Specifically, entrepreneurial self-efficacy was examined to understand 
leader influence toward HEI performance and sustainability, since entrepreneurship can only be achieved through human effort, knowledge, and skills (Frydman, Hessel, Rapaczynski, \& Rizzo, 2000; Koh \& Hatten, 2002). In fact, Jeraj and Marič (2013) posited that the role of entrepreneurs in today's modern economy could not be ignored because they are an indispensable factor in achieving organisational success. This may not be unconnected with the fact that leaders or entrepreneurs with higher ESE are more likely to respond to challenges of today's environment (Chen et al., 1998). Moreover, while most of the studies focused on the composite entrepreneurial self-efficacy (Bratkovic, Antoncic, \& DeNoble, 2012), this renders ESE dimensions to be rarely investigated despite the robustness of the construct (Mcgee, Peterson, Mueller, \& Sequeira, 2009). Therefore, the present study aimed at providing new understanding of the influence of individual dimensions of ESE on HEI performance. This is in line with the conclusion by Cumberland, Meek, and Germain (2015), that understanding the individual effect will go a long way in better identifying the most needed ESE component in a particular sector. In essence, different sectors may require different ESE components that are the most vital in that organisation or sector. Hence, it will be logical if these components are understood and arranged hierarchically according to the needs of the organisation. For example, HEIs are not fully profit-making organisations and as such it can be assumed that the most important ESE components arranged according to importance should be management ESE, financial control ESE, marketing ESE, innovation ESE, and finally risk taking ESE.

\section{Entrepreneurial Self-Efficacy (ESE) and HEI Performance}

Self-efficacy was defined as the perceived ability of an individual in performing a given task (Bandura, 1977, 1986). Self-efficacy is built on four basic foundations of individual judgment, social pressure, enactive mastery, as well as experience and influence of role model (Bandura, 1977, 1986). Furthermore, the focal point of social cognitive theory (SCT) established the existence of a mutual relationship between individual characteristics, behavioural factors, and environmental factors (Chen et al., 1998; Shea \& Howell, 2000). In fact, self-efficacy is related to individual trust in executing a particular action which affects the cognitive aspect (Harrison, Chadwick, \& Scales, 1996; Kuo, Chu, Hsu, \& Hsieh, 2004). Consequently, the basic findings of Bandura submitted that individuals with high self-efficacy are more likely to take bold actions than those with low self-efficacy. However, 
the concept of self-efficacy has gone beyond individual motivation, since has the ability to predict both entrepreneurial intention, job, and organisational performance (Chen et al., 1998; Stajkovic \& Luthans, 1998).

In entrepreneurship, scholars conceptualised self-efficacy as taskspecific in nature, referred to as entrepreneurial self-efficacy (ESE). ESE was defined as the individual's ability to successfully engage and execute any entrepreneurial activities (Chen et al., 1998). Most entrepreneurs are self-efficacious in nature (Bradley \& Roberts, 2004), thus the conclusion that ESE is a distinctive characteristic that can differentiate entrepreneurs from non-entrepreneurs (Chen et al. 1998). Also, ESE significantly affects opportunity recognition (Ozgen \& Baron, 2007) and also influences the persistence and perseverance to ensure successful utilisation of the said opportunity (Chen, Gully, \& Eden, 2004; Mitchell \& Shepherd, 2010). In essence, despite the ESE construct being very recent (Chen et al., 1998; De Noble et al., 2007), its role in determining and explaining entrepreneurial action is significant (Bandura, 1986; Zhao, Seibert, \& Hills, 2005). Hence, understanding ESE is very important, as it does not only explain the behaviours of those who are willing to be entrepreneurs, but those who are already entrepreneurs (Li \& Jing, 2008). Also, ESE is a task specific construct that recognises both individual and environmental characteristics about entrepreneurial action (Boyd \& Vozikis, 1994; Chen et al., 1998).

Consequently, several studies established the link between ESE with entrepreneurial intention, and firm performance, growth, and renewal (Baum \& Locke, 2004; Bird, 1988; Boyd \& Vozikis, 1994; Bratkovic et al., 2012; Hmieleski \& Baron, 2008). Specifically, Hallak, Lindsay, and Brown (2011) expanded the reliability and theoretical backing of the ESE construct by conducting a study within the tourism sector. Interestingly, the study established that ESE of the tourism entrepreneur affects the performance of their firm. Similarly, in a bid to further expand and validate the ESE construct, Hallak, Assaker, and O'Connor (2012) also conducted a study on the impact of ESE in the tourism sector. Using a sample of both family and non-family tourism business owners, the study was able to provide validity on the impact of ESE on firm performance. Recently in a meta-analysis, Miao, Qian, and Ma (2016) used a total of 26 samples to establish that ESE has a significant positive effect on firm performance. ESE is vital in predicting entrepreneurial activities and also the outcome of these activities. 
It is clear from the above that these studies had provided a link between composite ESE and performance. However, most studies looked at the overall effect of ESE construct, hence, there is a need to understand the effect of the individual components of the ESE construct, as developed by (Chen et al., 1998). Consequently, studies started responding to the need for understanding the effect of the individual ESE dimensions and performance. For example, Neri, Torres, and Watson (2013) also conducted a study on the impact of ESE on entrepreneurial intention and performance in Mexico. However, despite using the original dimensions (Chen et al., 1998), they went ahead and conducted a confirmatory factor analysis (CFA) to further create a new ESE measure with three dimensions. Specifically, the new routine, expansion, and knowledge measures were established to affect performance. In addition, they also established the effect of the new measures on entrepreneurial intention (Chen et al., 1998). Similarly, Mahmood and Mahmood (2014) also conducted a study on the effect of individual dimensions of ESE as developed previously (De Noble, Jung, \& Ehrlich, 1999). They also provided empirical evidence on the effect of individual dimensions on firm performance. Recently, Cumberland et al. (2015) conducted a similar study in the franchise industry, where they established a significant link between all the five dimensions to firm performance. In the light of the above justification, it was hypothesised that:

H1: Management ESE is positively related to HEI performance.

H2: Financial control ESE is positively related to HEI performance.

H3: Marketing ESE is positively related to HEI performance.

H4: Innovation ESE is positively related to HEI performance.

H5: Risk taking ESE is positively related to HEI performance.

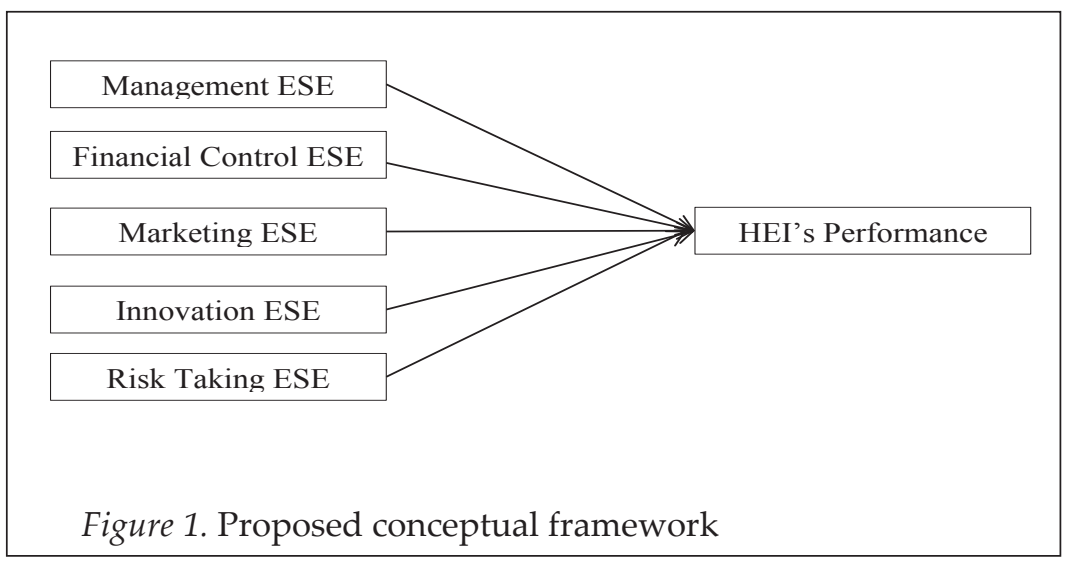




\section{Methodology}

\section{Research Instruments}

The research instruments were adapted from previous studies; specifically, entrepreneurial self-efficacy was adapted from Chen et al. (1998), while the performance was adapted from Brewer and Selden (1998), Choi and Rainey (2010), Morris and Jones (1999), Moynihan and Pandey (2005), and Pitt and Tucker (2008). The ESE is divided into six sub-dimensions with 22 items and nine items for OP measured on a seven-points Likert scale ranging from strongly agree (1) to strongly disagree (7); consistent with previous studies that mid-point scales provide better information, reliability, and results (Dawes, 2008).

\section{Sample Design and Data Collection}

Before the main data collection process, a total of 50 questionnaires were distributed, out of which only 31 were used for a pilot test, presenting a $62 \%$ response rate. The pilot test is an avenue where the clarity and validity of the questions representing the variables are tested in a new context, after which some adjustment can be made to enhance understanding of the respondents. Using a nonprobability sampling technique, the study generated 225 returned questionnaires to represent a $56.3 \%$ response rate, after distributing 400 questionnaires among academic leaders of selected HEIs in Kano, Nigeria. Out of these numbers, only 180 questionnaires were completed correctly and deemed fit for further analysis. According to the results from the respondents, demographic characteristics are as follows: the majority of respondents were male representing $67.4 \%$ of the total population size, while the rest were female $32.6 \%$. Similarly, the majority of respondents fell between the ages of 25 to 40 , representing $67.4 \%$, while the remaining $32.6 \%$ were aged 41 and above. In addition, a large number of respondents were from the arts and humanities and management sciences departments and faculties, making up for $58 \%$, while the remaining $42 \%$ were from sciences and other none-business related departments.

Accordingly, the study also conducted the Common Method Variance (CMV) test to vindicate that the validity and reliability of the data had not originated from the same source. Podsakoff, MacKenzie, Lee, and Podsakoff (2003) viewed that the likelihood of bias is high when data of both the dependent and independent variables originated from the same source hence there is a need to evaluate data to ensure that it is 
free from CMV. In line with this argument, one of the most common methods was utilised, namely the Herman's factor, to observe if $\mathrm{CMV}$ is an issue in the present study. Interesting, the data of the study indicated that CMV is not a problem as none of the variables explained more than 50\%, as suggested by Podsakoff et al. (2003). Specifically, the data of the study had only $26 \%$ of variance explained by a single variable.

\section{Result}

\section{Data Analysis}

After testing the reliability and validity of the construct using the pilot test, the main data was also screened in line with Tabachnick and Fidell (2007)), where both multivariate and univariate outliers were detected and deleted. In addition, the Skewness and Kurtosis analysis was also conducted and values of both variables fell within the accepted threshold. Consequently, the data were analysed using SmartPLS version 3, where the measurement model and the structural model were established. SmartPLS was identified as one of the most suitable tools of analysis because it accommodates both small sample size as well as relatively normally distributed data (Chin, 1998). Furthermore, SmartPLS can accommodate both reflective and formative models (Hair, Hult, Ringle, \& Sarstedt, 2014), and also can run multiple regressions simultaneously. The measurement model analysis differs with the type of construct, e.g., reflective or formative constructs. Reflective constructs are expected to be highly correlated and can be used interchangeably; while formative are the opposite of the reflective constructs (Chin, 1998).

The present study constructs were both reflective in nature, thus there is a need to assess reliability and validity. Specifically, a reflective measurement model involves three main tests, namely internal consistency, and convergent and discriminant validity (Roldán \& Sanchez-Franco, 2012). The internal consistency was validated using three different criteria of Cronbach's Alpha, Rho_A, and Composite Reliability (CR) using a threshold of 0.70. Table 1 indicates that Cronbach's alpha, Rho_A, and CR have adequate loadings to satisfy the internal consistency reliability. Hence, the evaluation of the convergent validity to ensure that the items put together explain at least $50 \%$ of the construct. Using a threshold of an average variance explained (AVE) value of 0.50 as suggested by Hair et al. (2014), 
IJMS 23 (2), 119-137 (2017)

Table 1 shows that all the values are greater than 0.50 to justify the convergent validity of the items.

Table 1

Factor Loadings, Composite Reliability, and Average Variance Extracted

\begin{tabular}{|c|c|c|c|c|c|c|}
\hline Construct & Items & Loadings & $\begin{array}{l}\text { Cronbach's } \\
\text { Alpha }\end{array}$ & Rho_A & $\mathrm{CR}$ & AVE \\
\hline \multirow[t]{3}{*}{ FC ESE } & FCESE1 & 0.885 & 0.657 & 0.853 & 0.772 & 0.538 \\
\hline & FCESE2 & 0.703 & & & & \\
\hline & FCESE3 & 0.579 & & & & \\
\hline \multirow[t]{4}{*}{ INN ESE } & INNESE1 & 0.714 & 0.769 & 0.785 & 0.824 & 0.540 \\
\hline & INNESE2 & 0.678 & & & & \\
\hline & INNESE3 & 0.795 & & & & \\
\hline & INNESE4 & 0.748 & & & & \\
\hline \multirow[t]{4}{*}{ MGT ESE } & MGTESE2 & 0.725 & 0.799 & 0.863 & 0.857 & 0.600 \\
\hline & MGTESE3 & 0.791 & & & & \\
\hline & MGTESE4 & 0.807 & & & & \\
\hline & MGTESE5 & 0.773 & & & & \\
\hline \multirow[t]{6}{*}{ MKT ESE } & MKTESE1 & 0.838 & 0.932 & 0.956 & 0.945 & 0.741 \\
\hline & MKTESE2 & 0.882 & & & & \\
\hline & MKTESE3 & 0.861 & & & & \\
\hline & MKTESE4 & 0.880 & & & & \\
\hline & MKTESE5 & 0.840 & & & & \\
\hline & MKTESE6 & 0.863 & & & & \\
\hline \multirow[t]{7}{*}{ PERF } & OP1 & 0.802 & 0.894 & 0.897 & 0.917 & 0.611 \\
\hline & OP2 & 0.769 & & & & \\
\hline & OP4 & 0.820 & & & & \\
\hline & OP5 & 0.754 & & & & \\
\hline & OP6 & 0.747 & & & & \\
\hline & OP8 & 0.797 & & & & \\
\hline & OP9 & 0.781 & & & & \\
\hline \multirow[t]{4}{*}{ RT ESE } & RTESE1 & 0.763 & 0.763 & 0.769 & 0.853 & 0.597 \\
\hline & RTESE2 & 0.867 & & & & \\
\hline & RTESE3 & 0.847 & & & & \\
\hline & RTESE4 & 0.579 & & & & \\
\hline
\end{tabular}


Finally, Table 2 and 3 display the discriminant validity using Fornell and Larcker (1981), and Henseler et al. (2015) multitrait-multimethod matrix. The Fornell and Larcker (1981) method is one of the most common methods of checking discriminant validity at the construct level. The values of the reflective variables are compared with the square root of the AVE (off-diagonal) to ensure that construct is more correlated with measures of the parent construct to indicate adequate discriminant validity. Recently, the Fornell and Larcker was found wanting, hence the heterotrait-monotrait (HTMT) ratio of correlations was introduced as the new way of validating discriminant validity (Henseler, Ringle, \& Sarstedt, 2015). Specifically, an HTMT value of .85 is considered as a strict threshold to ensure discriminant validity. It is fair to conclude that the model has achieved internal consistency, and convergent and discriminant validity, and consequently, the determination of the structural model.

Table 2

Fornell-Larcker Discriminant Validity

\begin{tabular}{lcccccc}
\hline & FC ESE & INN ESE & MGT ESE & MKT ESE & PERF & RT ESE \\
\hline FC ESE & $\mathbf{0 . 7 3 3}$ & & & & & \\
INN ESE & 0.112 & $\mathbf{0 . 7 3 5}$ & & & & \\
MGT ESE & 0.221 & 0.237 & $\mathbf{0 . 7 7 5}$ & & & \\
MKT ESE & 0.103 & 0.481 & 0.191 & $\mathbf{0 . 8 6 1}$ & & \\
PERF & 0.578 & 0.259 & 0.427 & 0.168 & $\mathbf{0 . 7 8 2}$ & \\
RT ESE & 0.505 & 0.334 & 0.640 & 0.323 & 0.658 & $\mathbf{0 . 7 7 2}$ \\
\hline
\end{tabular}

Table 3

Heterotrait-monotrait ratio (HTMT)

\begin{tabular}{lcccccc}
\hline & FC ESE & INN ESE & MGT ESE & MKT ESE & PERF & RT ESE \\
\hline FC ESE & & & & & & \\
INN ESE & 0.187 & & & & & \\
MGT ESE & 0.201 & 0.219 & & & & \\
MKT ESE & 0.251 & 0.541 & 0.184 & & & \\
PERF & 0.605 & 0.252 & 0.437 & 0.168 & & \\
RT ESE & 0.570 & 0.41 & 0.718 & 0.381 & 0.787 & \\
\hline
\end{tabular}


In essence, the study had fully satisfied all the necessary tests to ensure a fit and satisfactory measurement model, as identified above; the next is the estimation of the structural model parameters to determine $R^{2}$, path coefficient, effect-size $\left(F^{2}\right)$, and model fit using predictive relevance $\left(Q^{2}\right)$. In estimating the above, the study utilised the 500 bootstrapping algorithm resampling technique (Hair, Ringle, \& Sarstedt, 2011).

\section{Structural Model}

Having satisfied all the requirements of the measurement model of reflective constructs, next, the structural model was assessed by evaluating the path coefficient, co-efficient of determination $\left(R^{2}\right)$, effect size $\left(F^{2}\right)$, and the predicative relevance $\left(Q^{2}\right)$, in line with the recommendations by Hair et al. (2014). The path coefficient and $R^{2}$ are the preliminary requirements of the structural model (Rasoolimanesh, Jaafar, Badarulzaman, \& Ramayah, 2015). The path coefficient explains the relationship between exogenous and endogenous variables, while $R^{2}$ explains the variance explained by each exogenous variable in the study, which varies according to the research area. Prior to structural model validation, the model fit indices were examined using standard root mean residual (SRMR) as the only available method in PLS-SEM (Jörg Henseler, Hubona, \& Ray, 2016). Accordingly, an SRMR value of 0.08 or less would be considered enough and good for the fit of any model in PLS-SEM (Hu \& Bentler, 1999). In the present study, a value of 0.076 was found to provide a reasonable model fit.

Following the achievement of the validity and quality of the measurement model, the structural model was evaluated by using the 5000 bootstrapping resampling technique. The structural model involves two basic preliminary assessments of $R^{2}$ and the path coefficient, in line with the hypothesised relationship. According to Chin (2010), $R^{2}$ values falls into three main categories, namely substantial 0.67 , moderate 0.33 , and weak 0.19 . The $R^{2}$ value of the study fell into the moderate category with a value of 0.523 . Specifically, the exogenous variable of the study explains $52 \%$ of the variance that occurs to the endogenous variable. To assess a reliable path coefficient, the bootstrapping and the percentile bootstrap confidence interval of $95 \%$ was used.

Accordingly, the path coefficient of the relationship between ESE dimensions and HEI performance using 5000 bootstrapping was tested. Specifically, financial control ESE, innovation ESE, and risk 
IJMS 24 (1), 119-137 (2017)

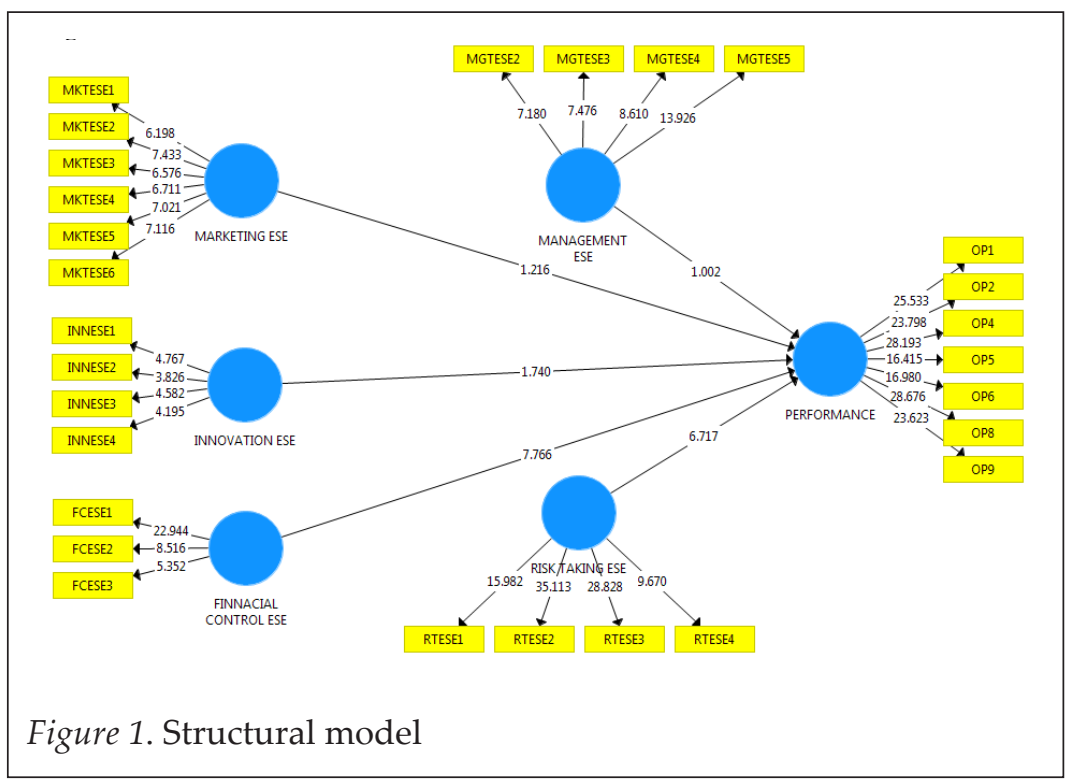

taking ESE were found to significantly affect HEI performance. As shown in Figure 1 and Table XX, financial control ESE has a statistical significance to HEI performance $(\beta=0.340, t=7.776, p=0.000)$; hence, accepted. Innovation ESE also had a significant and positive relationship with HEI performance $(\beta=0.092, t=1.740, p=0.040)$. As a result the hypothesis was accepted. Similarly, risk taking ESE reported $(\beta=0.434, t=6.717, p=0.000)$ to indicate a significant and positive relationship with HEI performance. On the contrary, the relationship between management ESE reported an insignificant relationship with HEIs performance with a $\beta=-0.065, t=1.002, p=0.157$, which necessitated the rejection of the hypothesis. Moreover, Marketing ESE relationship with HEI performance was also rejected with a $\beta=-0.064$, $\mathrm{t}=1.216$, $\mathrm{p}=0.117$.

Table 4

Structural Model Path Coefficient

\begin{tabular}{cccccccc}
\hline Hypothesis & Beta & $\begin{array}{c}\text { Stand. } \\
\text { Error }\end{array}$ & T-Statistics & P-Values & $5 \%$ & $95 \%$ & Decision \\
\hline FC ESE -> PERF & 0.340 & 0.043 & 7.776 & 0.000 & 0.261 & 0.403 & YES \\
INN ESE -> PERF & 0.092 & 0.052 & 1.740 & 0.040 & 0.002 & 0.174 & YES \\
\hline & & & & & & & (continued)
\end{tabular}


IJMS 23 (2), 119-137 (2017)

\begin{tabular}{cccccccc}
\hline Hypothesis & Beta & $\begin{array}{c}\text { Stand. } \\
\text { Error }\end{array}$ & T-Statistics & P-Values & $5 \%$ & $95 \%$ & Decision \\
\hline MGT ESE -> PERF & 0.065 & 0.064 & 1.002 & 0.157 & -0.054 & 0.161 & NO \\
MKT ESE -> PERF & -0.064 & 0.054 & 1.216 & 0.117 & -0.169 & 0.009 & NO \\
RT ESE -> PERF & 0.434 & 0.064 & 6.717 & 0.000 & 0.34 & 0.548 & NO \\
\hline
\end{tabular}

Having satisfied the basic requirements of the inner model, the $f$ and $Q^{2}$ were analysed to determine the effect of the exogenous variable on the endogenous variable and also the predictive relevance of the whole model. According to Cohen (1988), $f^{2}$ values of 0.02, 0.15, and 0.35 manifest small, medium, and large effects, respectively. In the present study, FC ESE and RT ESE recorded a moderate effect size of 0.18 and 0.16, while INN ESE, MGT ESE, and MKT ESE recorded a small effect of $0.13,0.05$, and 0.06 respectively. The study also evaluated the predictive relevance $\left(Q^{2}\right)$ of the model using the Stone-Geisser test. The predictive relevance is explained as the "measure of how wellobserved values are reconstructed by the model and its parameter estimates" (Chin, 1998). $Q^{2}$ is established through blindfolding, and a result or value greater than zero signifies that the model has predictive relevance. For this study, the model has predictive relevance because it recorded a value of 0.287 , which is greater than zero.

\section{Conclusion and Implications}

The main aim of the study was to identify the effect of ESE dimensions on HEI performance. The study was based on the fact that, organisations around the world are facing serious economic changes in today's dynamic environment which necessitate adopting new means to enhance performance. ESE has received much attention over the years, especially within the business settings. ESE relationship with performance has been fully documented (Jeraj \& Marič, 2013). However, findings were not always consistent. Moreover, few studies (Cumberland et al., 2015) examined the effect of ESE dimensions in profit-making sectors, unlike this study which focused on nonprofit sectors like HEIs. For public sector organisations, and HEIs in particular, to survive in today's environment, there is a need to identify factors important for private sector performance; one of which is ESE. This study has argued and provided a broader analysis of ESE dimensions in HEI performance, which provides an important extension of ESE dimensions to the field and literature.

Specifically, the study provided insight on the impact of manager attitude and behaviour for effective decisions and action that enhances 
organisational performance. In fact, the study has further validated the BarNir (2012) assertion, which states that leaders' entrepreneurial capabilities are vital for any organisation to achieve greater performance. Moreover, the study provided further justifications for HEIs where ESE dimension is important and the one they need to work on to enhance their performance. Overall, the study had further validated previous arguments on the impact of individual effect of ESE on the performance of not only new businesses (Drnovšek, Wincent, \& Cardon, 2010), but also existing ones, such as HEIs.

Furthermore, this research has further validated the study by Cumberland et al. (2015) where they established that all five ESE dimensions affect the performance of a franchising firm. However, the present study only established three main ESE factors that affect HEI performance. The failure of the management and marketing ESE factors to yield similar significant results may not be unconnected with Chen, Greene, and Crick (1998) assertion that ESE performance relationship solely depends on organisational culture. Hence, there is potentially a need for management to consider enhancing the remaining two ESE dimensions to increase performance by providing a supportive environment, which is lacking in most government organisations.

Despite the contribution of the study, there are some limitations which can be further addressed in future studies. Specifically, this study did not attempt to control for difference in experience and also specialisation into business related and non-business related fields. It has been argued that leaders' experience may influence individual ESE (Cassar \& Friedman, 2009), but at the same time it was argued that leaders of business related department or faculty would be more likely to exhibit ESE better than non-business departments. Consequently, future study should control for experience and specialisation to expand the findings of this study. Another limitation of this study was that it utilised only academic leaders while ignoring another individuals, who may likely play an important role in enhancing performance of the organisation, thus their ESE may also be put into consideration in future studies. This will also provide an avenue for future leader selection from various departments of the institutions.

\section{References}

Ahmad, N. H., Halim, H. A., Ramayah, T., \& Rahman, S. A. (2013). Revealing an open secret: Internal challenges in creating an 
entrepreneurial university from the lens of the academics. International Journal of Conceptions on Management and Social Sciences, 1(1), 2357-2787.

Amin, M., Ismail, W. K. W., Rasid, S. Z. A., \& Selemani, R. D. A. (2014). The impact of human resource management practices on performance: Evidence from a Public University. The TQM Journal, 26(2), 125-142. http://doi.org/10.1108/TQM-10-20110062

Bakar, M. S. (2014). Mediating effect of intrapreneurial orientation on the relationship between leadership style, knowledge sharing behavior and performance of academic leaders in Malaysia. University Utara Malaysia.

Bakar, M. S., \& Mahmood, R. (2014). Linking Transformational Leadership and Corporate Entrepreneurship to Performance in the Public Higher Education Institutions in Malaysia. Advances in Management and Applied Economics, 4(3), 109.

Bandura, A. (1977). Toward a unifying theory of behavioral change. Psychological Review, 84(2), 191.

Bandura, A. (1986). The explanatory and predictive scope of selfefficacy theory. Journal of Social and Clinical Psychology, 4(3), 359-373.

BarNir, A. (2012). Starting technologically innovative ventures: reasons, human capital, and gender. Management Decision, 50(3), 399-419.

Baum, J. R., \& Locke, E. a. (2004). The relationship of entrepreneurial traits, skill, and motivation to subsequent venture growth. The Journal of Applied Psychology, 89(4), 587-598. http://doi. org/10.1037/0021-9010.89.4.587

Berman, E., \& West, J. (1998). Responsible risk-taking. Public Administration Review. Retrieved from http://www.jstor.org/ stable/977564

Bird, B. (1988). Implementing Entrepreneurial Ideas: The Case for Intention. Academy of Management Review, 13(3), 442-453. http:// doi.org/10.5465/AMR.1988.4306970

Boyd, N. G., \& Vozikis, G. S. (1994). The influence of self-efficacy on the development of entrepreneurial intentions and actions. Entrepreneurship Theory and Practice, 18, 63.

Bratkovic, T., Antoncic, B., \& DeNoble, A. F. (2012). Relationships Between Networking, Entrepreneurial Self-Efficacy and Firm Growth: the Case of Slovenian Companies. Ekonomska Istrazivanja-Economic Research, 25(1), 73-87. http://doi.org/10.1 080/1331677X.2012.11517494 
Brewer, G. A., \& Selden, S. C. (2016). Whistle Blowers in the Federal Civil Service : New Evidence of the Public Service Ethic. Journal of Public Administration Research and Theory, 8(3), 413-439.

Callagher, L., Blixens, K., Horst, M., \& Husted, K. (2015). Exploring societal responses towards managerial prerogative in entrepreneurial universities. International Journal of Learning and Change, 8(1), 64-82.

Cassar, G., \& Friedman, H. (2009). Does self efficacy affect entrepreneurial investment. Strategic Entrepreneurship Journal, 3(3), 241-260. http://doi.org/10.1002/sej

Chen, C. C., Greene, P. G., \& Crick, A. (1998). Does entrepreneurial self-efficacy distinguish entrepreneurs from managers? Journal of Business Venturing, 13(4), 295-316. http://doi.org/10.1016/ S0883-9026(97)00029-3

Chen, G., Gully, S. M., \& Eden, D. (2004). General self-efficacy and self-esteem: Toward theoretical and empirical distinction between correlated self-evaluations. Journal of Organisational Behavior, 25(3), 375-395. http://doi.org/10.1002/job.251

Chin, W. (1998). The partial least squares approach to structural equation modeling. Modern Methods for Business Research, 295(2), 295-336. http://doi.org/10.1016/j.aap.2008.12.010

Chin, W. W. (1998). Commentary: Issues and Opinion on Structural Equation Modeling. MIS Quarterly, 22(1), 7-16. http://doi.org/ Editorial

Choi, S., \& Rainey, H. G. (2010). Managing diversity in U.S. federal agencies: Effects of diversity and diversity management on employee perceptions of organisational performance. Public Administration Review, 70(1), 109-121. http://doi.org/10.1111/ j.1540-6210.2009.02115.x

Cohen, J. (1988). Statistical power analysis for the behavioral sciences. Statistical Power Analysis for the Behavioral Sciences. http://doi. org/10.1234/12345678

Cumberland, D. m., Meek, W.r., \& Germain, R. (2015). Entrepreneurial Self-Efficacy And Firm Performance In Challenging Environments: Evidence From The Franchise Context. Journal of Developmental ..., 20(1), 19. http://doi.org/10.1142/ S1084946715500041

Danish, R. Q., \& Usman, A. (2010). Impact of Reward and Recognition on Job Satisfaction and Motivation: An Empirical Study from Pakistan. International Journal of Business and Management, 5(2001), 159-167. http://doi.org/10.5539/ijbm.v5n2P159

Dawes, J. (2008). Do data characteristics change according to the number of scale points used? An experiment using 5 point, 
7 point and 10 point scales. International Journal of Market Research, 50(1).

De Noble, A. F., Jung, D., \& Ehrlich, S. B. (1999). Entrepreneurial self -efficacy: The development of a measure and its relationship to entrepreneurial action. Frontiers of Entrepreneurship Research, 73-87.

Dike, V. E. (2014). Leadership and the Nigerian Economy. SAGE Open, 4(1), 10. http://doi.org/10.1177/2158244014523792

Drnovšek, M., Wincent, J., \& Cardon, M. S. (2010). Entrepreneurial self-efficacy and business start-up: developing a multidimensional definition. International Journal of Entrepreneurial Behaviour \& Research, 16(4), 329-348. http://doi. org/10.1108/13552551011054516

Elliott, R. (2008). Strathprints Institutional Repository. Psychotherapy Research, 22, 1753-1759. http://doi.org/10.1016/j. buildenv.2006.10.027

Ferretti, M., \& Parmentola, A. (2015). The University-Driven LISs. In The Creation of Local Innovation Systems in Emerging Countries (pp. 91-114). Springer. http://doi.org/10.1007/978-3-319-104409

Fornell, C., \& Larcker, D. (1981). Evaluating structural equation models with unobservable variables and measurement error. Journal of Marketing Research, 18(3), 39-50. http://doi.org/10.2307/3151312

Frydman, R., Hessel, M. P., Rapaczynski, A., \& Rizzo, M. J. (2000). Why ownership matters? Entrepreneurship and the restructuring of enterprises in Central Europe. Entrepreneurship and the Restructuring of Enterprises in Central Europe (April 1998). Columbia Law School, Law-Econ Working Paper, (172). http://doi. org/10.2139/ssrn.194574

H.M.A, H., Mahmood, R., \& Mahmood, H. H. M. A. and R. (2014). Dimensions of Entrepreneurial Self-Efficacy and Firm Performance. Global Journal of Management and Business Research: A Administration and Management, 14(4).

Hair, J. F. J., Hult, G. T. M., Ringle, C., \& Sarstedt, M. (2014). A Primer on Partial Least Squares Structural Equation Modeling (PLSSEM). Long Range Planning (Vol. 46). Thousand Oaks, CA: SAGE Publications, Incorporated. http://doi.org/10.1016/j. lrp.2013.01.002

Hair, J. F., Ringle, C. M., \& Sarstedt, M. (2011). PLS-SEM: Indeed a Silver Bullet. The Journal of Marketing Theory and Practice, 19(2), 139-152. http://doi.org/10.2753/MTP1069-6679190202

Hallak, R., Assaker, G., \& O'Connor, P. (2012). Are Family and Nonfamily Tourism Businesses Different? An Examination of 
the Entrepreneurial Self-Efficacy-Entrepreneurial Performance Relationship. Journal of Hospitality \& Tourism Research, XX(X), 1-26. http://doi.org/10.1177/1096348012461545

Hallak, R., Lindsay, N. J., \& Brown, G. (2011). Examining the role of entrepreneurial experience and entrepreneurial self-efficacy on SMTE performance. Tourism Analysis, 16(5), 583-599.

Harrison, J. K., Chadwick, M., \& Scales, M. (1996). The relationship between cross-cultural adjustment and the personality variables of self-efficacy and self-monitoring. International Journal of Intercultural Relations, 20(2), 167-188. http://doi. org/10.1016/0147-1767(95)00039-9

Henseler, J., Hubona, G., \& Ray, P. A. (2016). Using PLS path modeling in new technology research: updated guidelines. Industrial Management \& Data Systems, 116(1), 2-20. http://doi. org/10.1108/02635570710734262

Henseler, J., Ringle, C. M., \& Sarstedt, M. (2015). A new criterion for assessing discriminant validity in variance-based structural equation modeling. Journal of the Academy of Marketing Science, 43(1), 115-135. http://doi.org/10.1007/s11747-014-0403-8

Hmieleski, K. M., \& Baron, R. A. (2008). When does entrepreneurial self-efficacy enhance versus reduce firm performance. Strategic Entrepreneurship Journal, 2(1), 57-72. http://doi.org/10.1002/ sej.42

Hu, L., \& Bentler, P. M. (1999). Cutoff criteria for fit indexes in covariance structure analysis: Conventional criteria versus new alternatives. Structural Equation Modeling: A Multidisciplinary Journal, 6(1), 1-55. http://doi.org/10.1080/10705519909540118

Jeraj, M., \& Marič, M. (2013). Relation between Entrepreneurial Curiosity and Entrepreneurial Self-efficacy: a Multi-Country Empirical Validation. Organisacija, 46(6), 264-273. http://doi. org/10.2478/orga-2013-0027

Kearney, C., \& Morris, M. H. (2015). Strategic renewal as a mediator of environmental effects on public sector performance. Small Business Economics, 45(2), 425-445. http://doi.org/10.1007/ s11187-015-9639-z

Koh, K., \& Hatten, T. (2002). The tourism entrepreneur: The overlooked player in tourism development studies. International Journal of Hospitality \& Tourism Administration, 3(1), 21-48. http://doi. org/10.1300/J149v03n01

Kuo, F. Y., Chu, T. H., Hsu, M. H., \& Hsieh, H. S. (2004). An investigation of effort-accuracy trade-off and the impact of selfefficacy on Web searching behaviors. Decision Support Systems, 37(3), 331-342. http://doi.org/10.1016/S0167-9236(03)00032-0 
Lew, T. (2009). Perceived Organisational Support: Linking Human Resource Management Practices with Affective Organisational Commitment, Professional Commitment and Turnover Intention. The Journal of International Management Studies, 4(2), 104-115.

Li, J., \& Jing, L. (2008). The evolution of entrepreneurial intention in transition environment*: Toward an entrepreneurial selfefficacy based model. 2008 International Conference on Wireless Communications, Networking and Mobile Computing, WiCOM 2008, 2006-2009. http://doi.org/10.1109/WiCom.2008.1436

Mcgee, J. E., Peterson, M., Mueller, S. L., \& Sequeira, J. M. (2009). Entrepreneurial self-efficacy: Refining the measure. Entrepreneurship: Theory and Practice, 33(4), 965-988. http://doi. org/10.1111/j.1540-6520.2009.00304.x

Miao, C., Qian, S., \& Ma, D. (2016). The Relationship between Entrepreneurial Self-Efficacy and Firm Performance: A MetaAnalysis of Main and Moderator Effects. Journal of Small Business Management, 0(0), 1-21. http://doi.org/10.1111/jsbm.12240

Mitchell, J. R., \& Shepherd, D. A. (2010). To thine own self be true: Images of self, images of opportunity, and entrepreneurial action. Journal of Business Venturing, 25(1), 138-154. http://doi. org/10.1016/j.jbusvent.2008.08.001

Morris, M. H., \& Jones, F. F. (1999). Entrepreneurship in established organisations: The case of the public sector. Entrepreneurship Theory and Practice, 24(1), 73-93. Retrieved from http://search. ebscohost.com/login.aspx?direct=true\&db=buh\&AN=2808242 \&site $=$ ehost-live

Moynihan, D. P., \& Pandey, S. K. (2005). Testing how management matters in an era of government by performance management. Journal of Public Administration Research and Theory, 15(3), 421439.

Neri Torres, J. L., \& Watson, W. (2013). An examination of the relationship between manager self-efficacy and entrepreneurial intentions andperformance in mexican small businesses. Contaduría Y Administración, 58(3), 65-87. http://doi.org/10.1016/ S0186-1042(13)71222-1

Ozgen, E., \& Baron, R. A. (2007). Social sources of information in opportunity recognition: Effects of mentors, industry networks, and professional forums. Journal of Business Venturing, 22(2), 174-192. http://doi.org/10.1016/j.jbusvent.2005.12.001

Pitt, M., \& Tucker, M. (2008). Performance measurement in facilities management: driving innovation? Property Management, 26(4), 241-254. http://doi.org/10.1108/02637470810894885 
Podsakoff, P. M., MacKenzie, S. B., Lee, J.-Y., \& Podsakoff, N. P. (2003). Common method biases in behavioral research: a critical review of the literature and recommended remedies. The Journal of Applied Psychology, 88(5), 879-903. http://doi. org/10.1037/0021-9010.88.5.879

Rasoolimanesh, S. M., Jaafar, M., Badarulzaman, N., \& Ramayah, T. (2015). Investigating a framework to facilitate the implementation of city development strategy using balanced scorecard. Habitat International, 46, 156-165. http://doi. org/10.1016/j.habitatint.2014.12.003

Roldán, J. L., \& Sanchez-Franco, M. J. (2012). Variance-based structural equation modeling: guidelines for using partial least squares in information systems research. In M. Mora O. Gelman, A. Steenkamp, \& M. Raisinghani (Eds.), Research methodologies, innovations and philosophies in software systems engineering and information systems (In Raising, pp. 193-221). Hershey PA: Information Science Reference.

Shea, C. M., \& Howell, J. M. (2000). Efficacy-Performance Spirals: An Empirical Test. Journal of Management, 26(4), 791-812. http://doi. org/10.1177/014920630002600409

Stajkovic, A. A. D., \& Luthans, F. (1998). Self-efficacy and workrelated performance: A meta-analysis. Psychological Bulletin, 124(2), 240.

Tabachnick, B. G., \& Fidell, L. S. (2007). Using multivariate statistics. Using Multivariate Statistics 5th Ed, 980. http://doi. org $/ 10.1037 / 022267$

Wahab, A., Mahmood, R., \& Bakar, S. Bin. (2015). How do self-efficacy and learning orientation affect performance of university leaders? Journal for Studies in Management and Planning, 1(5), 501-514.

Zhao, H., Seibert, S. E., \& Hills, G. E. (2005). The mediating role of self-efficacy in the development of entrepreneurial intentions. The Journal of Applied Psychology, 90(6), 1265-1272. http://doi. org/10.1037/0021-9010.90.6.1265 